\title{
Quality parameters of digital aerial survey and airborne laser scanning covering the entire area of the Czech Republic
}

\author{
Jiří Šíma \\ Novorossijská 18, Praha 10, Czech Republic \\ jirka.sima@quick.cz
}

\begin{abstract}
The paper illustrates the development of digital aerial survey and digital elevation models covering the entire area of the Czech Republic at the beginning of 21st century. It also presents some results of systematic investigation of their quality parameters reached by the author in cooperation with Department of Geomatics at the Faculty of Applied Sciences of the University of Western Bohemia in Pilsen and the Land Survey Office.
\end{abstract}

Keywords: digital aerial survey, orthophoto imagery, aerial laser scanning, digital elevation model, digital surface model, Czech Republic

\section{Introduction}

Year 2010 became a turning point as far as gathering of up-to-date geospatial data from the whole territory of the Czech Republic concerned. Aerial survey with digital cameras in RGB and NIR spectral bands with on-the-ground resolution of $0.20 \mathrm{~m}$ covered $100 \%$ of the state territory in the course of 2010-12. Periodically repeated digital image records serve as a database for photogrammetric processing - preferentially of digital colour orthoimagery of the Czech Republic with on-the-ground resolution of $0.25 \mathrm{~m}$. The era of taking aerial photographs on film and their subsequent rastering by means of precise photogrammetric scanners was de facto closed for this purpose. At the same time aerial laser scanning of $68.4 \%$ of the state territory was successfully realized within the Project of New Hypsometry of the Czech Republic [1]. Its main goal is to provide bodies of state administration with High Resolution Elevation Data in form of Digital Elevation Model and Digital Surface Model of the entire state territory by 2015. New models of hypsometry will fulfil all requirements of the INSPIRE project as well. The Czech Office for Surveying, Mapping and Cadastre, Ministry of Defence and Ministry of Agriculture are investors of both projects. Land Survey Office and Military Geographical and Hydrometeorological Office are main compilers of digital image and LIDAR data. The author and Department of Geomatics at the Faculty of Applied Sciences of the University of West Bohemia in Pilsen have collaborated in definition and evaluation of quality parameters of all resulting products from the very beginning of development of all above mentioned projects.

\section{Development of aerial survey for production of the CZ Orthophoto}

In order to reach complete coverage of the Czech Republic with aerial photographs or digital images in 3year period total area of $78865 \mathrm{~km} 2$ was divided into 3 zones (West, Central, East) in 2003 respecting the layout of the State map series in scale 1 : 5000 (Fig.1). From 2003 to 
2008 wide angle aerial photographs, mostly in scale $1: 23000$ from relative flight height 3500 $\mathrm{m}$ have been exposed on colour negative film and transformed into raster form by precise photogrammetric scanners. Such parameters allowed to produce digital colour orthophoto imagery with pixel size $0.50 \mathrm{~m}$ on the ground. Since 2009 orthophoto imagery with higher resolution ( $0.25 \mathrm{~m}$ on the ground) has been required and other survey flight parameters photo scale 1:18 000 and lower flight height $2740 \mathrm{~m}$ have to be chosen.

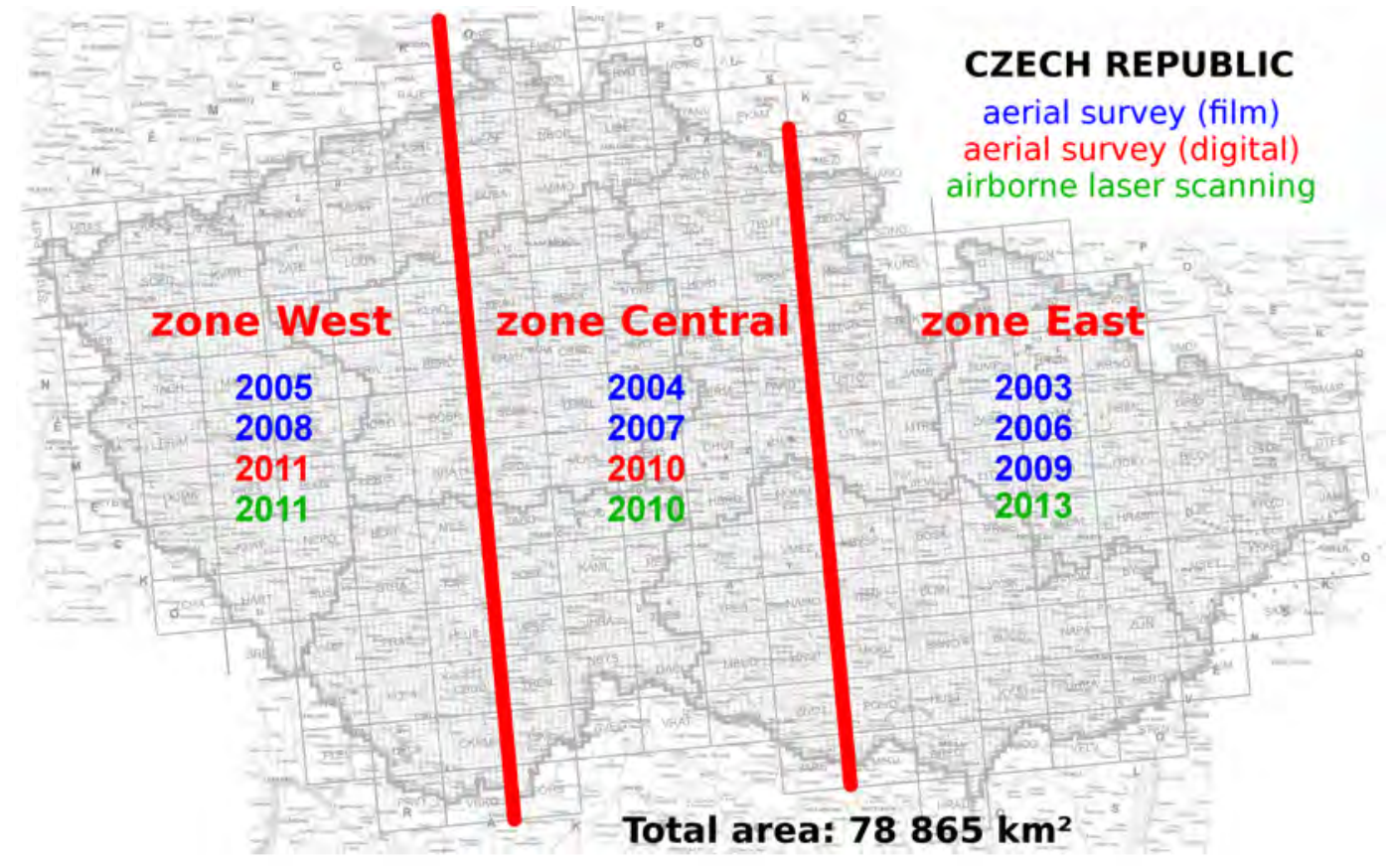

Figure 1: Schedule of aerial survey and airborne laser scanning of the Czech Republic

Since 2010 aerial photography on a film has been replaced by digital aerial survey using digital large format metric cameras for simultaneous registration of images in PANCHRO, R,G,B and NIR spectral bands. Minimum size of a sensor element 6 micrometers allowed to reach economically the on-the-ground resolution between 20 and $25 \mathrm{~cm}$ of the pixel size. All private firms taking part in tenders for digital aerial survey have used Vexcel UltraCam X or Xp cameras. Table 1 shows a complete review of methods used for aerial survey of the entire area of the Czech Republic [4].

Digital aerial survey covered the Central zone in 2010 and the zone-West in 2011. The rest of state territory ( $22.8 \%$ - almost 28 thousand $\mathrm{km}^{2}$ in zone-East) was imaged in 2012 commonly with one half of the Central zone, because there is an intention to reduce recent 3-year period into 2-year period since 2012. (Fig. 2). All projects of aerial surveys have been funding by the Czech Office for Surveying, Mapping and Cadastre and the Ministry of Agriculture.

The main product of periodical aerial surveys - the CZ Orthophoto (Ortofoto ČR in Czech) serves first of all for needs of state authorities and public administration. Some important examples of its application should be introduced here:

- updating of the Land Parcel Information System; orthophoto is documenting the areas recently cultivated by farmers when they ask for financial support from the funds of 
Š́́ma, J.: Quality PARAMETERS of Digital AERIAL SURVEy ...

\begin{tabular}{|c|l|c|c|}
\hline Year & Method of aerial survey and rastering & $\begin{array}{c}\text { Average scale of } \\
\text { photographs / images }\end{array}$ & $\begin{array}{c}\text { On-the ground pixel size } \\
\text { (pixel of CZ Orthophoto) }\end{array}$ \\
\hline \hline $2003-2008$ & $\begin{array}{l}\text { analogue, on colour film } \\
\text { + scanning into the raster form }\end{array}$ & $1: 23000$ & $\begin{array}{c}0.46-0.48 \mathrm{~m} \\
(0.50 \mathrm{~m})\end{array}$ \\
\hline \multirow{2}{*}{2009} & $\begin{array}{l}\text { analogue, on colour film } \\
\text { + scanning into the raster form }\end{array}$ & $1: 18000$ & $\begin{array}{c}0.27 \mathrm{~m} \\
(0.25 \mathrm{~m})\end{array}$ \\
\hline \multirow{2}{*}{2010} & $\begin{array}{l}\text { digital (PAN, R, G, B, NIR) } \\
\text { direct raster registering - UC XP }\end{array}$ & $1: 32000$ & $\begin{array}{c}0.19 \mathrm{~m} \\
(0.25 \mathrm{~m})\end{array}$ \\
\hline \multirow{2}{*}{2011} & $\begin{array}{l}\text { digital (PAN, R, G, B, NIR) } \\
\text { direct raster registering - UC X, XP }\end{array}$ & $1: 35000$ & $\begin{array}{c}0.21-0.25 \mathrm{~m} \\
(0.25 \mathrm{~m})\end{array}$ \\
\hline \multirow{2}{*}{2012} & $\begin{array}{l}\text { digital (PAN, R, G, B, NIR) } \\
\text { direct raster registering - UC XP }\end{array}$ & $1: 36000$ & $\begin{array}{c}0.22 \mathrm{~m} \\
(0.25 \mathrm{~m})\end{array}$ \\
\hline
\end{tabular}

Table 1: Recent development of aerial survey parameters for the CZ Orthophoto production

European Union,

- updating of the Fundamental Base of Geographic Data (known under acronym ZABAGED (B) that is a topological-vectorial spatial data base at level of $1: 10000$ Base Map of the Czech Republic,

- updating of a military Digital Landscape Model 25, a similar database at level of $1: 25000$ Military Topographic Map,

- providing the Infrastructure for Spatial Information in Europe (INSPIRE) with recent orthophoto imagery of the Czech Republic.

- as an substantial part of the Digital Map of Public Administration.

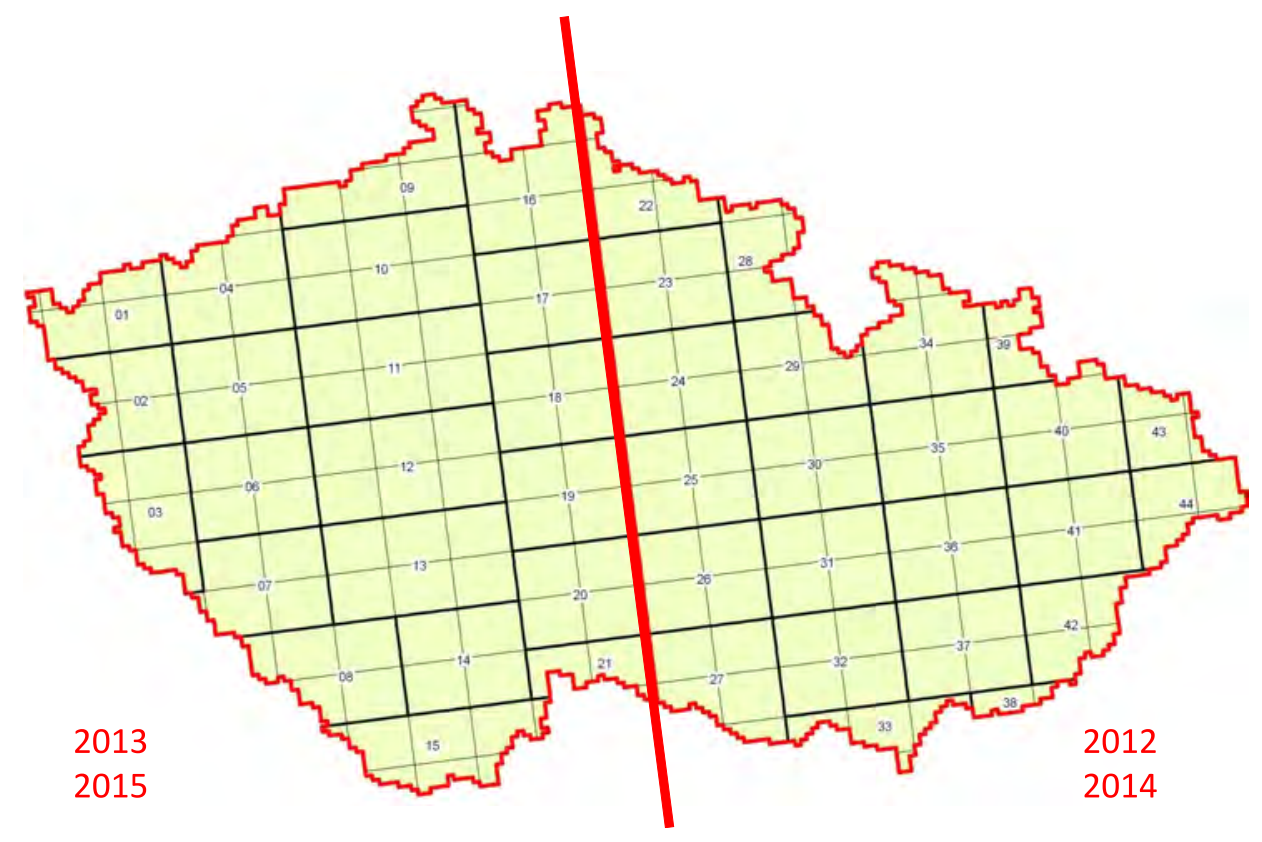

Figure 2: Digital aerial survey of the Czech Republic in two-year interval since 2012 


\section{Quality parameters of the CZ Orthophoto}

The quality of the CZ Orthophoto enables to use this product to some other tasks [6]:

- discovering some discrepancies, gross and systematic positional errors in planimetric representation of objects in digitized cadastral maps (see Fig. 3),

- colour infrared orthophotos are widely used to national inventory of forests.

From 2004 the Laboratory of digital photogrammetry at the Faculty of Applied Sciences in Pilsen, and later the author in collaboration with Department of land surveying of the Land Survey Office have been continuously assessing the absolute positional accuracy of the CZ Orthophoto [4] using more test fields containing hundreds of check points measured mostly by GPS Real Time Kinematic method with positional accuracy better than $10 \mathrm{~cm}$, and identical points well identified in the orthophoto. Remarkable seems to be high absolute positional accuracy of orthophoto from digital images in spite of their distinctly lesser scale [5] [8] [9] (see Table 2).

\begin{tabular}{|l|c|c|c|c|c|c|c|c|}
\hline $\begin{array}{l}\text { Method of image } \\
\text { data registering }\end{array}$ & $\begin{array}{c}\text { Number } \\
\text { of points }\end{array}$ & $\begin{array}{c}\mathrm{cY} \\
{[\mathrm{m}]}\end{array}$ & $\begin{array}{c}\mathrm{cX} \\
{[\mathrm{m}]}\end{array}$ & $\begin{array}{c}\mathrm{mY} \\
{[\mathrm{m}]}\end{array}$ & $\begin{array}{c}\mathrm{mX} \\
{[\mathrm{m}]}\end{array}$ & $\begin{array}{c}\mathrm{mXY} \\
{[\mathrm{m}]}\end{array}$ & $\begin{array}{c}\Delta \mathrm{Ymax} \\
{[\mathrm{m}]}\end{array}$ & $\begin{array}{c}\Delta \mathrm{Xmax} \\
{[\mathrm{m}]}\end{array}$ \\
\hline $\begin{array}{l}\text { colour film } \\
1: 16650(2008) \\
\text { raster scanning } \\
\text { pixel size } 20 \mu \mathrm{m}\end{array}$ & 732 & -0.17 & 0.08 & 0.36 & 0.33 & $\mathbf{0 . 3 5}$ & 1.88 & -1.67 \\
\hline $\begin{array}{l}\text { digital images } \\
1: 32 \text { 000 }(2010) \\
\text { pixel } 6 \text { or } 7.2 \mu \mathrm{m}\end{array}$ & 430 & 0.05 & -0.03 & 0.14 & 0.16 & $\mathbf{0 . 1 5}$ & 0.55 & 0.60 \\
\hline $\begin{array}{l}\text { digital images } \\
1: 35000(2011) \\
\text { pixel size } 6 \mu \mathrm{m}\end{array}$ & 301 & 0.02 & 0.07 & 0.21 & 0.24 & $\mathbf{0 . 2 3}$ & 0.63 & 0.89 \\
\hline $\begin{array}{l}\text { digital images } \\
1: 36 \text { 000 }(2012) \\
\text { pixel size } 6 \mu \mathrm{m}\end{array}$ & 90 & $.0,04$ & -0.05 & 0.20 & 0.23 & $\mathbf{0 . 2 2}$ & 0.48 & 0.53 \\
\hline
\end{tabular}

Explanations: c . . s systematic error

$\mathrm{m}$ root mean square error

$\Delta \max$ maximum error

Table 2: Results of testing the absolute positional accuracy of the CZ Orthophoto

Following check point types have been chosen for evaluation of absolute positional accuracy of the CZ Orthophoto:

- visible on-the-ground corners of a building

- foot of a pylon, telegraph pole or lamppost

- on-the-ground corner of a fence, underpinning or masonry wall

- midpoint of a circular manhole, drainage and well cover,

- corner of a kerb or road surface

- $\mathrm{X}$ or $\mathrm{T}$ form of white line intersections on a road surface 


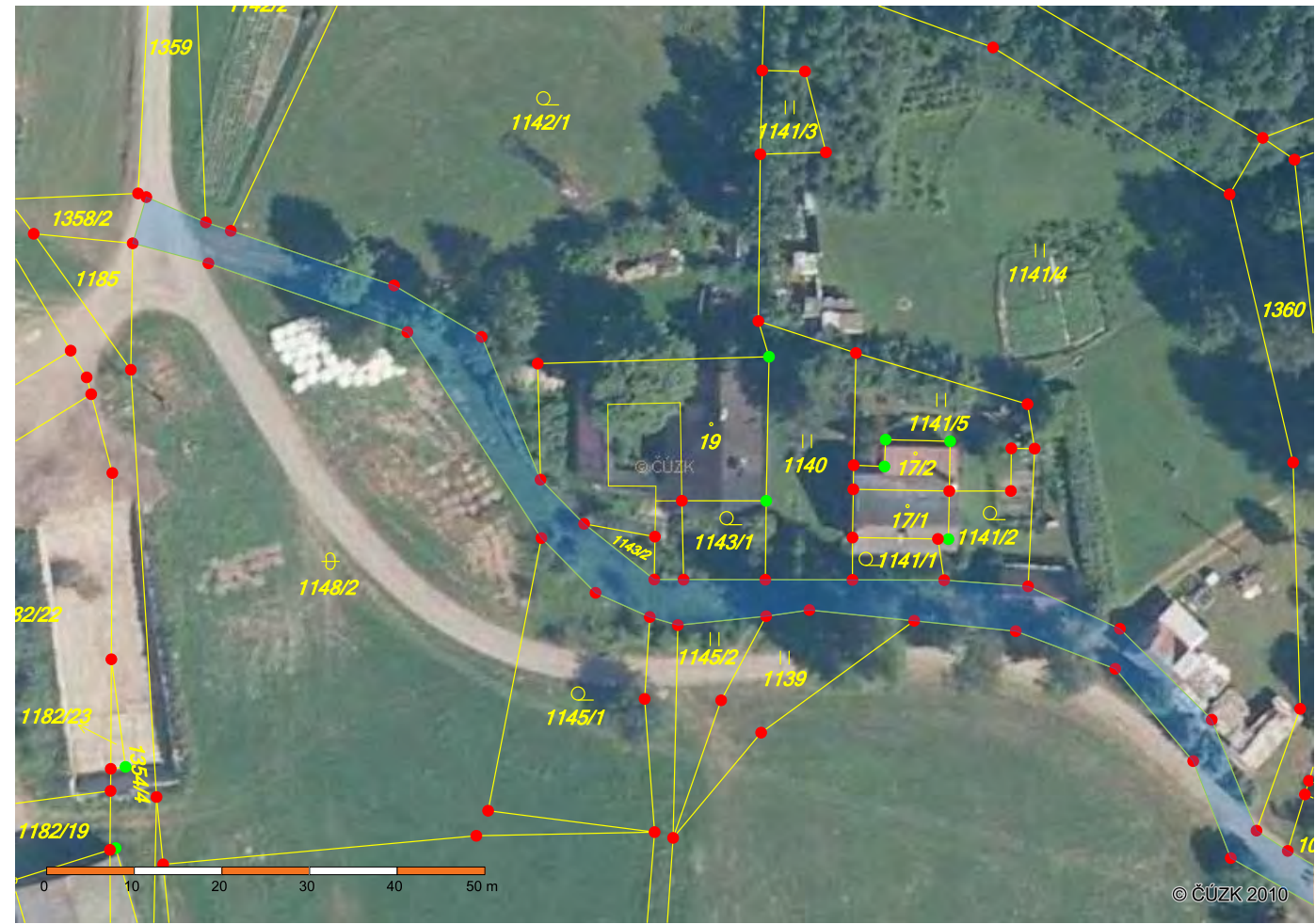

Figure 3: Original cadastral survey of a local road 50 years ago and reality as shown in the CZ Orthophoto

High absolute positional accuracy of the CZ Orthophoto made from digital aerial images in 2010-12 (see Tab. 3) has been reached thanks to compliance with keeping of three principles:

1. targeting of optimally distributed ground control points within the block of aerial images; predominantly of monumented triangulation points having known and accurate absolute position defined in the compound coordinate reference system (S-JTSK, Baltpo vyrovnání). Their number should not be less than 1 per 25 digital images, e.g. 40 GCP within the block of 1000 images,

2. on-the-board registration of elements of exterior orientation by GPS/IMU apparatus that makes the spatial geometry of a block stronger,

3. modern and effective software for digital automatic aerotriangulation (AAT) that enables quickly change the input parameters and repeat the computation (MATCH-AT version 5.2.1 or 5.4.2 has been used in two processing centres).

\section{Development of digital elevation models in the Czech Republic}

Until the year 2000 the Czech Republic was completely covered with hypsography based on graphical contour lines with two-metre interval represented in the Base Map of the Czech Republic in scale 1: 10000 (Fig. 4). In the course of establishing the Fundamental Base of Geographic Data (ZABAGED®) in topological-vectorial form, above mentioned hypsography has been digitized into a 3D model forming the Triagulated Irregular Network called 
Š́́ma, J.: Quality PARAmeters of Digital AERIAl SURVEy ...

\begin{tabular}{|c|c|c|c|c|c|c|c|c|}
\hline \multirow{2}{*}{ Year } & \multirow{2}{*}{$\begin{array}{l}\text { Number } \\
\text { of AAT } \\
\text { blocks }\end{array}$} & \multicolumn{3}{|c|}{$\begin{array}{l}\text { RMSE of residuals on ground } \\
\text { control points use for AAT }\end{array}$} & \multirow{2}{*}{$\begin{array}{l}\text { Number } \\
\text { of AAT } \\
\text { blocks }\end{array}$} & \multicolumn{3}{|c|}{$\begin{array}{l}\text { RMSE of residuals on check } \\
\text { control points not use for AAT }\end{array}$} \\
\hline & & $\begin{array}{c}\mathrm{m}_{\mathrm{X}} \mathrm{AAT} \\
{[\mathrm{m}]}\end{array}$ & $\begin{array}{l}\mathrm{m}_{\mathrm{Y}} \mathrm{AAT} \\
{[\mathrm{m}]}\end{array}$ & $\begin{array}{c}\mathrm{m}_{\mathrm{H}} \mathrm{AAT} \\
{[\mathrm{m}]}\end{array}$ & & $\begin{array}{l}\mathrm{M}_{\mathrm{X}} \\
{[\mathrm{m}]}\end{array}$ & $\begin{array}{l}\mathrm{M}_{\mathrm{Y}} \\
{[\mathrm{m}]}\end{array}$ & $\begin{array}{l}\mathrm{M}_{\mathrm{H}} \\
{[\mathrm{m}]}\end{array}$ \\
\hline 2010 & 17 & 0.113 & 0.100 & 0.200 & $\overline{12}$ & 0.160 & 0.140 & 0.300 \\
\hline 2011 & 17 & 0.089 & 0.080 & 0.216 & 11 & 0.111 & 0.104 & 0.268 \\
\hline 2012 & 23 & 0.067 & 0.074 & 0.137 & 22 & 0.184 & 0.173 & 0.256 \\
\hline
\end{tabular}

Table 3: Results of testing the accuracy of digital automatic aerotriangulation

ZABAGED®-výškopis 3D vrstevnice. Another digital elevation model (DEM) in the form of $10 \times 10 \mathrm{~m}$ grid called ZABAGED® - 10x10 m grid was derived from the previous one.Typical elevation accuracy of those models is: $0.7-1.5 \mathrm{~m}$ in open terrain without continuous vegetation cover, $1-2 \mathrm{~m}$ in built-up areas and $2-5 \mathrm{~m}$ in forests (accidentaly up to $20 \mathrm{~m}$ in the mountains).
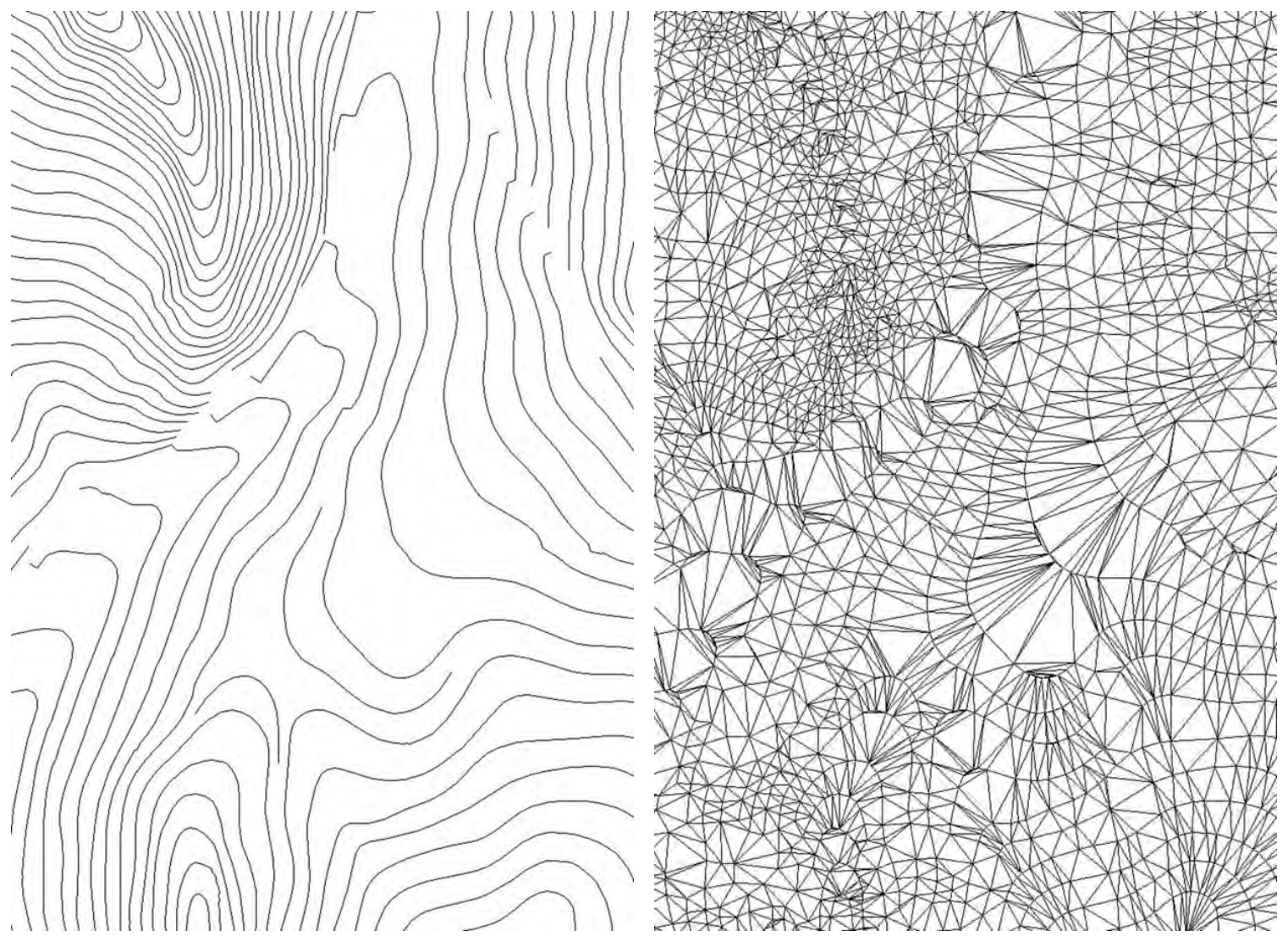

Figure 4: Original contour lines in the Base Map 1: 10000 and their TIN representation after vectorizing

More demanding requirements on elevation accuracy for production of orthophotos with high on-the-ground resolution ( $25 \mathrm{~cm}$ and better) and frequent demands for $3 \mathrm{D}$ modelling of terrain ground and surface iniciated generation of the Project of New Hypsometry of the Czech Republic within the period from 2009 to 2015. As the most effective method the airborne laser scanning (ALS) was chosen for this purpose [1] [7]. 


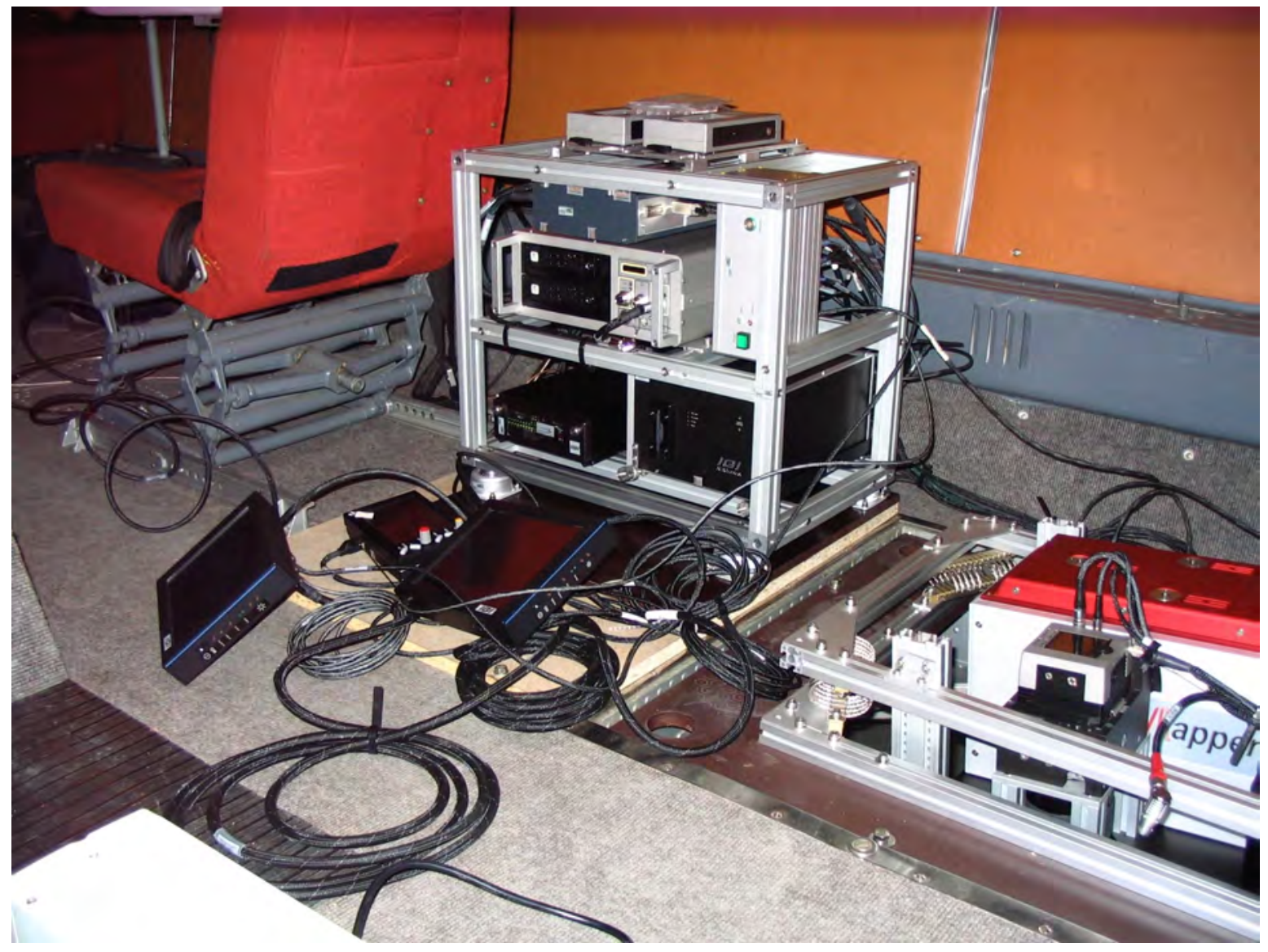

Figure 5: Laser scanning system LITEMAPPER on the board of L-410 FG aircraft

In contrast with gathering the aerial photos and digital images by Czech or foreign private firms only, the airborne laser scanning has been accomplished by three state administration authorities: Ministry of Defence, Ministry of Agriculture and the Czech Office for Surveying, Mapping and Cadastre. Their tasks have been distributed according to disponible capacities.

Army of the Czech Republic dispones with a special photogrammetric aircraft L-410 FG of the Czech production suitable for both airborne laser scanning and digital aerial survey as well. Usual speed of a survey flight or airborne laser scanning is $250 \mathrm{~km}$ per hour. The flight hights range from $1200 \mathrm{~m}$ to $3200 \mathrm{~m}$. In case of airborne laser scanning there is a Laser Scanning System LITEMAPPER hired out by German firm IGI installed on the board of L-410 FG (Fig.5). Parts of that system are: Laser Scanner RIEGL LMS Q680, GPS NovaTel equipment and IMU produced by the firm IGI.

Fig. 6 illustrates state of airborne laser scanning at the end of 2011. In 2012 the flights with L-410 FG had to be frozen through the necessity of its general overhaul. Individual blocks for laser scanning and data processing occupy the area from $10 \times 10 \mathrm{~km}$ up to $10 \mathrm{x}$ $40 \mathrm{~km}$ depending on maximum difference of elevations inside. The flight lines are parallel to E-cordinate axis of UTM projection used by the Army of the Czech Republic. There are two UTM 6-degree zones in the Czech Republic but a unique national coordinate reference system (S-JTSK) generally used by the civilian sector (e.g. in cadastre). 


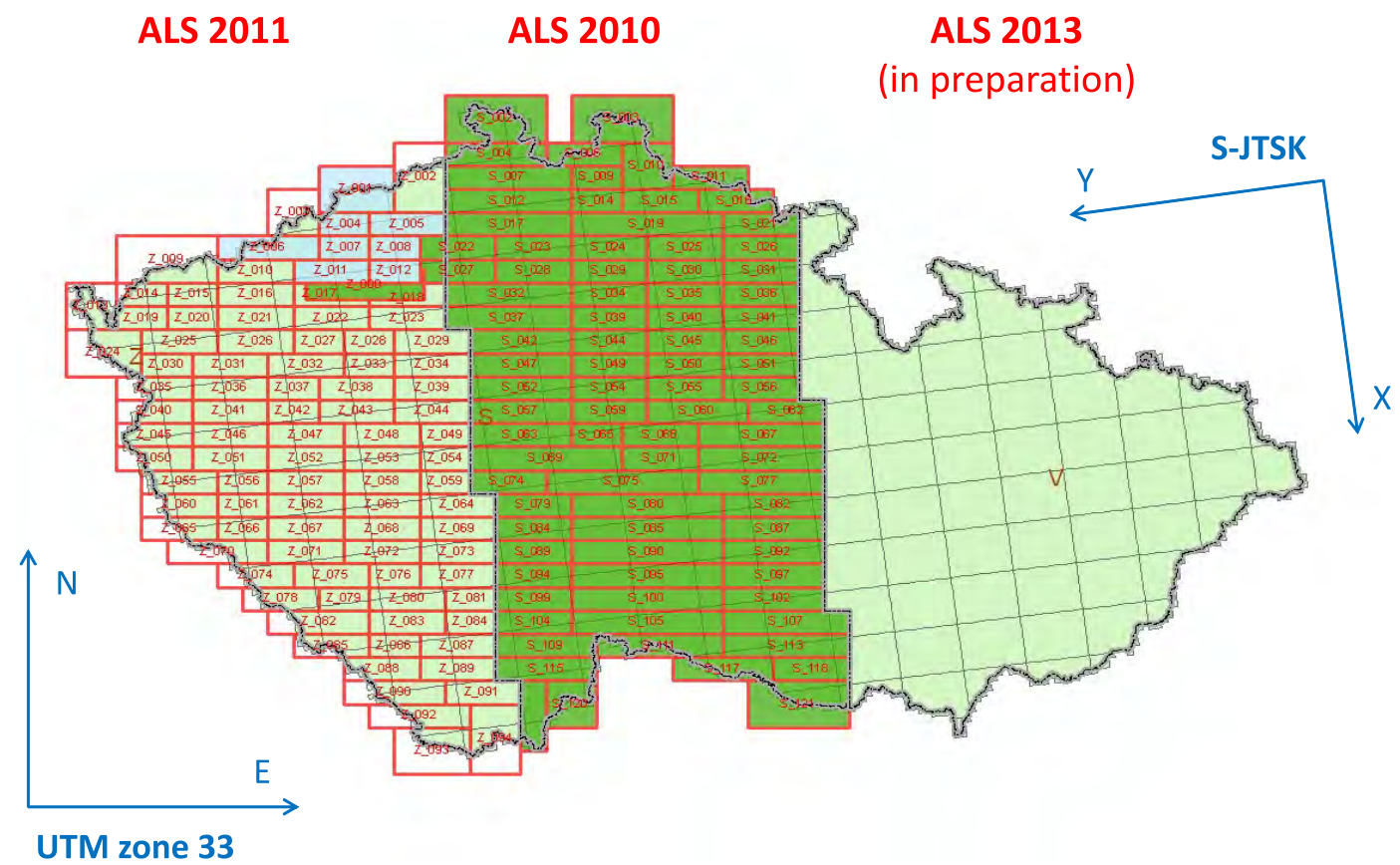

Figure 6: Coverage of the Czech Republic with airborne laser scanning data (March 2013)

\section{Quality parameters of new digital elevation models}

There are three final products of aerial laser scanning within the bounds of the Project of New Hypsomentry of the Czech Republic:

- Digital Elevation Model DMR 4G as a grid 5 x 5 m oriented paralelly to axes of national coordinate reference system S-JTSK or to the UTM grids in zones 33 and 34 (Fig. 7). This product should be always ready for distribution till 6 months after gathering ALS data. Its implicit elevation accuracy given by RMSE is $30 \mathrm{~cm}$ in open terrain and 1 metre in forested area. Suitable applications are: high resolution ortophoto production, draining of precipitation from a catchment basin, modelling of ecological disasters [2].

- Digital Ground Model DMR 5G in the form of Triangulated Irregular Network representing most of terrain break lines too should be ready for distribution till 12 months after gathering ALS data. Its implicit elevation accuracy given by RMSE is $18 \mathrm{~cm}$ in open terrain and $30 \mathrm{~cm}$ in forested area. Suitable applications are: new hypsometry of the Czech Republic (especially contour lines for State map series in scale from 1:5000 to 1 : 50 000), modelling of floods, modern spatial planning [3].

- Digital Surface Model (DMP 1G) ready for distribution till 18 months after gathering ALS data. Its implicit elevation accuracy given by RMSE is $40 \mathrm{~cm}$ on solid objects or bare ground and $70 \mathrm{~cm}$ on the surface with full-grown vegetation. Suitable applications are: optical visibility in rough terrain, night flying of helicopters, propagation of electromagnetic waves, true orthophoto in built-up areas.

The Land Survey Office organized a comprehensive testing for accuracy assessment of the DMR 4G using 240 horizontal test areas in Central zone of the Czech Republic (each equipped 


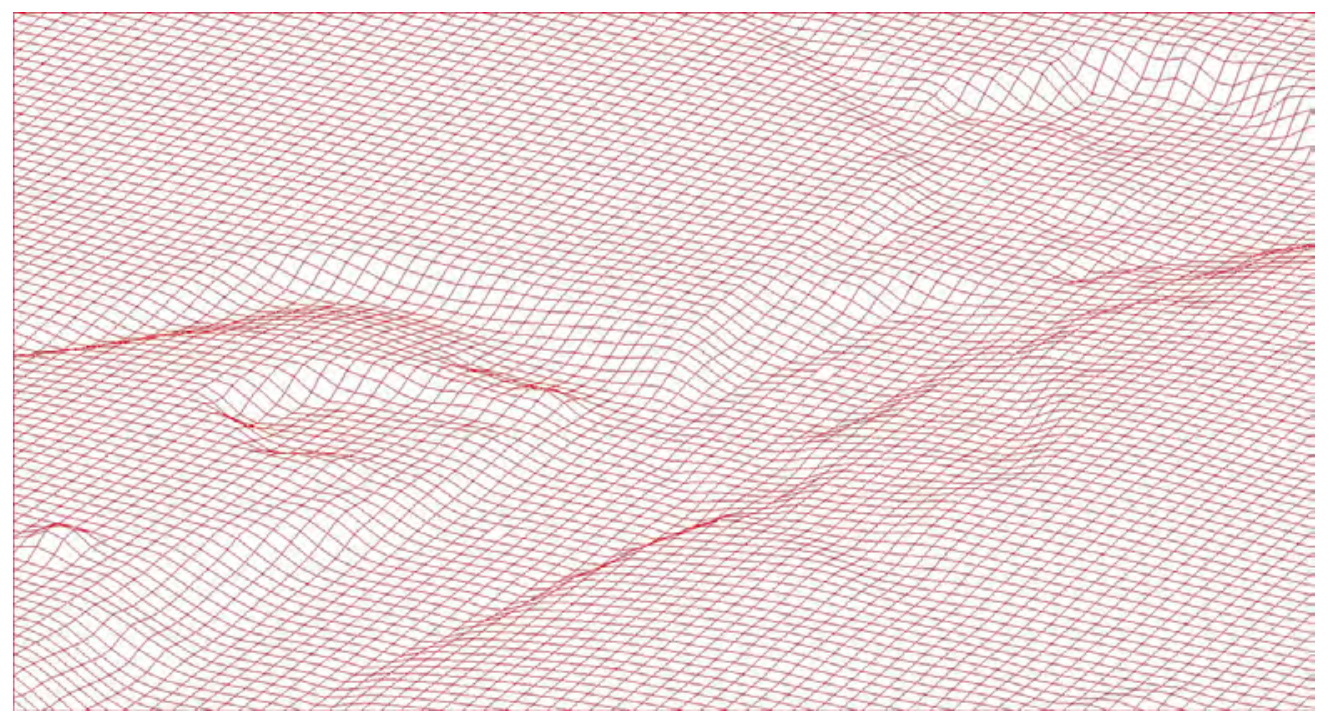

Figure 7: DMR 4G covering 68,4 \% of the Czech Republic (March 2013)

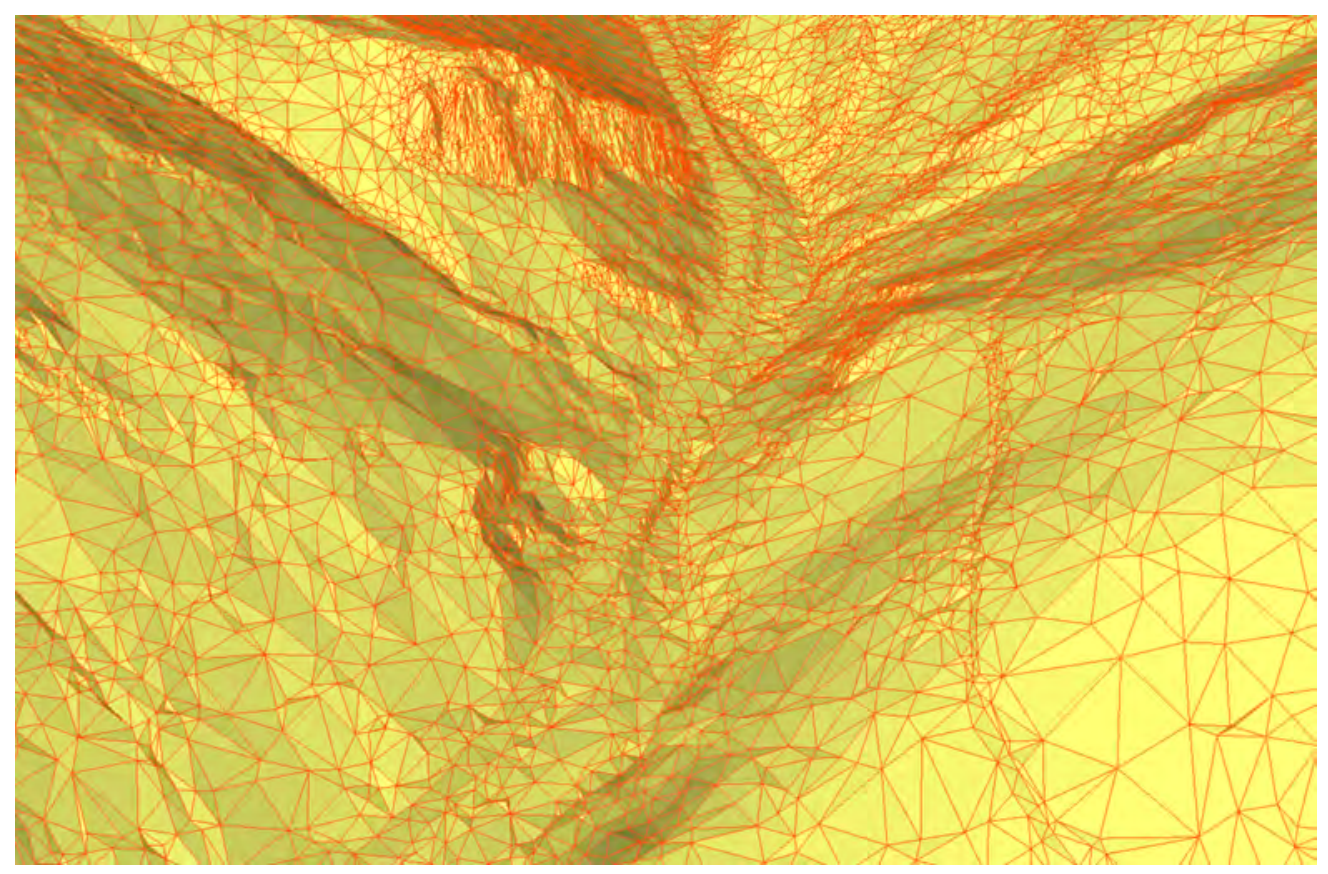

Figure 8: DMR 5G covering 33,4 \% of the Czech Republic (March 2013)

with $30-100$ check points) for determination of an average systematic error in elevations within the whole area mentioned above. It was $-0.15 \mathrm{~m}$ (under the ground surface). After mass elimination of this systematic error the standard deviation reached $0.08 \mathrm{~m}$ only!

970 representative points of terrain surfaces were chosen and geodetically measured in 6 terrain types with various land cover. The results of comparison with identical points (Table 4) interpolated from the grid $5 \times 5 \mathrm{~m}$ showed that expected elevation accuracy has been generally reached except for break lines of roads, embankments and trenches where this grid 


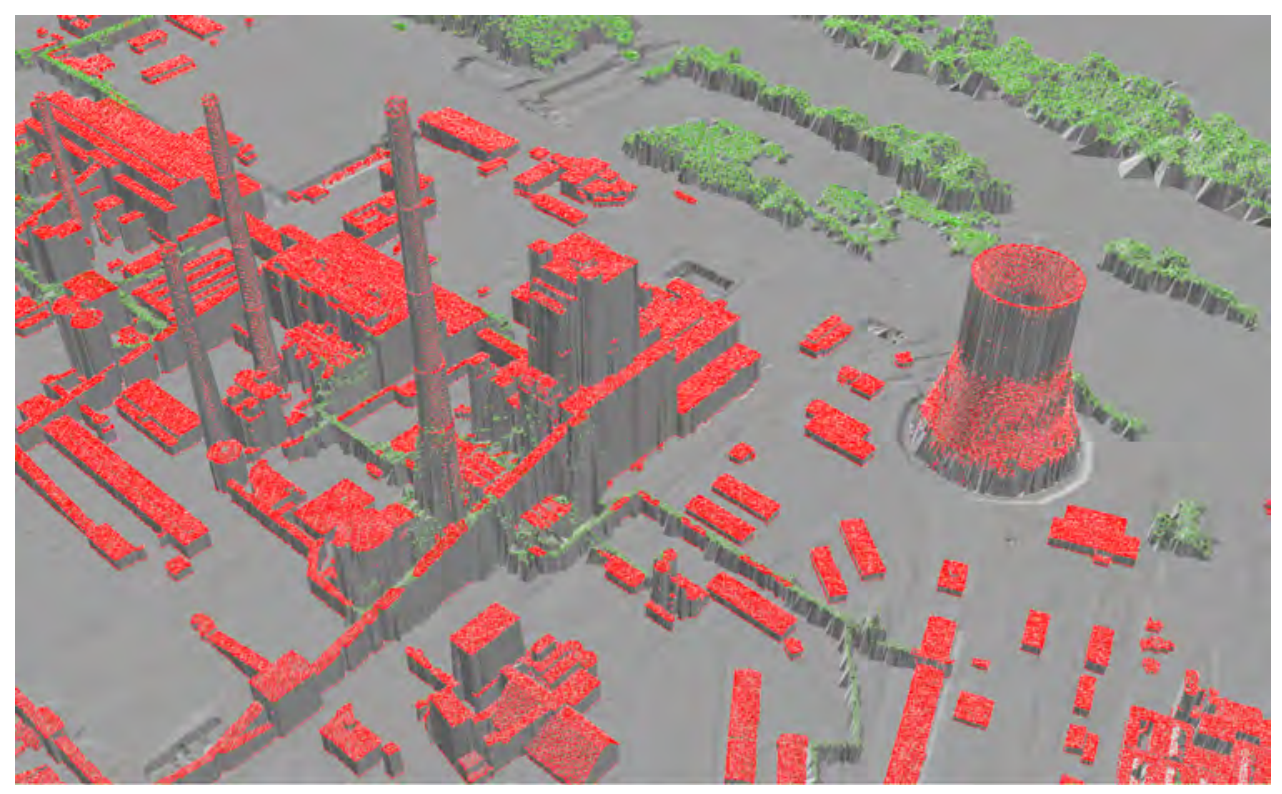

Figure 9: DMP 1G covering 32,9 \% of the Czech Republic (March 2013)

is too smooth for such an application [2].

\begin{tabular}{|l|c|c|c|}
\hline $\begin{array}{c}\text { Category of surface } \\
\text { and land cover }\end{array}$ & $\begin{array}{c}\text { Systematic error } \\
{[\mathrm{m}]}\end{array}$ & $\begin{array}{c}\text { RMSE }(\mathrm{H}) \\
{[\mathrm{m}]}\end{array}$ & $\begin{array}{c}\text { Maximum } \\
\text { error }[\mathrm{m}]\end{array}$ \\
\hline \hline Roads and highways & -0.25 & 0.34 & 0.77 \\
\hline Hard surfaces without vegetation & -0.01 & 0.07 & 0.26 \\
\hline Parks in built-up areas & -0.09 & 0.14 & 0.22 \\
\hline Arable land & -0.01 & 0.13 & 0.66 \\
\hline Meadows and pastures & -0.09 & 0.18 & 0.85 \\
\hline Shrubs, parkways, forests & -0.02 & 0.13 & 0.85 \\
\hline \hline \multicolumn{1}{|c|}{ Average value } & $\mathbf{- 0 . 0 8}$ & $\mathbf{0 . 1 7}$ & $\mathbf{0 . 6 0}$ \\
\hline
\end{tabular}

Table 4: Results of testing the DMR 4G elevation accuracy

That's why the main product of aerial laser scanning of the whole state territory will be the Digital Ground Model of 5th generation (DMR 5G). Its density (up to two points per square metre) allows to represent most of important terrain break lines, but it will be appropriately reduced on plane or less curved surfaces [3].

\begin{tabular}{|c|c|c|c|}
\hline $\begin{array}{c}\text { Category of surface } \\
\text { and land cover }\end{array}$ & $\begin{array}{c}\text { Systematic error } \\
{[\mathrm{m}]}\end{array}$ & $\begin{array}{c}\text { RMSE }(\mathrm{H}) \\
{[\mathrm{m}]}\end{array}$ & $\begin{array}{c}\text { Maximum } \\
\text { error }[\mathrm{m}]\end{array}$ \\
\hline \hline Break lines of roads and highways & -0.11 & 0.18 & 0.66 \\
\hline Hard surfaces without vegetation & -0.09 & 0.13 & 0.37 \\
\hline Arable land & -0.07 & 0.14 & 0.56 \\
\hline Meadows and pastures & -0.03 & 0.21 & 0.42 \\
\hline Shrubs, parkways, forests & -0.06 & 0.13 & 0.46 \\
\hline \hline Average value & $\mathbf{- 0 . 0 7}$ & $\mathbf{0 . 1 4}$ & $\mathbf{0 . 4 9}$ \\
\hline
\end{tabular}

Table 5: Results of testing the DMR 5G elevation accuracy 
Š́́ma, J.: Quality PARAMETERS of Digital AERIAL SURVEy ...

All products of digital aerial survey and airborne laser scanning from the entire area of the Czech Republic have been already/or will be step-by-step at disposal on Geoportal of the Czech Office for Surveying, Mapping and Cadastre (http://geoportal.cuzk.cz).

\section{Acknowledgment}

The author appreciates employees of the Land Survey Office for their cooperation, data providing and submitting several results of their analyses.

\section{References}

[1] Brázdil, K. (2009): Projekt tvorby nového výškopisu území České republiky. Geodetický a kartografický obzor, 2009, č. 7, pp. 145-151.

[2] Brázdil, K. et al (2010): Technická zpráva k digitálnímu modelu reliéfu 4. generace (DMR 4G). Zeměměřický úřad a Vojenský geografický a hydrometeorologický úřad. Dostupné z http://geoportal.cuzk.cz/Dokumenty/TECHNICKA_ZPRAVA_DMR_4G_15012012.pdf

[3] Brázdil, K. et al (2011): Technická zpráva k digitálnímu modelu reliéfu 5. generace (DMR 5G). Zeměměřický úřad a Vojenský geografický a hydrometeorologický úřad. Dostupné z http://geoportal.cuzk.cz/Dokumenty/TECHNICKA_ZPRAVA_DMR_5G.pdf

[4] Brázdil, K. et al (2012): Technická zpráva k ortofotografickému zobrazení území ČR (Ortofoto České republiky). Zeměměřický úřad a Vojenský geografický a hydrometeorologický úr̆ad. Dostupné z www.linkon.cz/gao6p

[5] Šíma, J. (2009): Průzkum absolutní polohové přesnosti ortofotografického zobrazení celého území České republiky s rozlišením 0,50, 0,25 resp. 0,20 m v území na Západočeské univerzitě v Plzni. Geodetický a kartografický obzor, 2009, č.9, pp. 214-220.

[6] Šíma, J. (2010): Nové zdroje geoprostorových dat pokrývajících celé území státu od roku 2010 - první výsledky výzkumu jejich kvalitativních parametrů. In: Sborník sympozia GIS Ostrava 2011. VŠB-TU Ostrava, 2011(nestránkováno). ISBN 978-80-248-2366-9.

[7] Šíma, J. (2011): Přríspěvek k rozboru přesnosti digitálních modelů reliéfu odvozených z dat leteckého laserového skenování celého území ČR. Geodetický a kartografický obzor, 2011, č. 5., pp. 101-106.

[8] Šíma, J. (2013): Digitální letecké měřické snímkování - nový impulz k rozvoji fotogrammetrie v České republice. Geodetický a kartografický obzor, 2013, č.1, pp. 15-21. Dostupné z http://egako.eu/wp-content/uploads/2012/11/gako_2013_01.pdf

[9] Švec, Z. (2013): Absolutní polohová přesnost Ortofota ČR vyhotoveného z digitálních leteckých měřických snímků . Geodetický a kartografický obzor, 2013, č.2, pp.31-38. Dostupné z http://egako.eu/wp-content/uploads/2012/11/gako_2013_02.pdf 
